\title{
Alternatif Perencanaan Jembatan Rangka Baja Dengan Menggunakan Metode Lrfd Di Jembatan Gelatik Kota Samarinda
}

\author{
Santi Yatnikasari ${ }^{1}$, Muhammad Noor Asnan ${ }^{2}$, Ulwiyah Wahdah Mufassirin Liana ${ }^{3}$ \\ Fakultas Sains dan Teknologi, Universitas Muhammadiyah Kalimantan Timur ${ }^{1,2,3}$ \\ email: sy998@umkt.ac.id ${ }^{1}$,mna985@umkt.ac.id²,uwm216@umkt.ac.id ${ }^{3}$ \\ DOI: http://dx.doi.org/10.31869/rtj.v4i2.2518
}

\begin{abstract}
Jembatan merupakan elemen penting dalam sistem transportasi. Jembatan adalah suatu konstruksi yang menghubungkan dua jalan yang terputus karena adanya jurang, lembah, sungai bahkan menghubungkan antar pulau yang terpisah cukup jauh. Jembatan rangka baja banyak dibangun untuk kepentingan lalu lintas jalan raya. Secara umum jembatan rangka baja lebih menguntungkan daripada jembatan lainnya, karena batang-batang utama rangka baja memikul gaya aksial tekan atau gaya aksial tarik, konstruksi jembatan jauh lebih ringan, bentang jembatan jauh lebih panjang, pelaksanaan dilapangan jauh lebih mudah. Struktur bangunan jembatan rangka baja terdiri atas beberapa bagian batang utama pembentuk rangka yaitu batang gelagar induk, batang gelagar melintang dan memanjang, batang-batang ikatan angin atas dan bawah, ikatan pengaku dan sistem lantai kendaraan yang membentuk suatu konstruksi yang kaku sehingga membentuk jalur lalu lintas yang aman dan nyaman. Tujuan dari penelitian ini adalah merencanakan ulang jembatan Gelatik menggunakan struktur jembatan rangka baja dengan metode Load And Resistance Factor Design (LRFD), dan mengacu pada peraturan Standar Nasional Indonesia (SNI). Profil baja yang digunakan pada perencanaan jembatan ini adalah profil baja WF untuk gelagar memanjang, gelagar melintang, gelagar induk, dan profil L untuk ikatan angin atas dan ikatan angin bawah.
\end{abstract}

Keywords: Jembatan Rangka Baja, Metode LRFD, Profil Baja

\section{PENDAHULUAN}

Perkembangan transportasi di Indonesia saat ini sangat pesat, sejalan dengan perkembangan teknologi dan industri. Pemerintah berusaha untuk menyediakan dan memenuhi kebutuhan dibidang transportasi. Pembangunan dilaksanakan guna meningkatkan pelayanan terhadap masyarakat terutama untuk mendapatkan fasilitas yang sebaik-baiknya dalam bidang transportasi. Prasarana transportasi bukan hanya jalan raya melainkan juga fasilitas pendukungnya. Oleh karena itu, upaya yang dilakukan pemerintah untuk meningkatkan sarana penghubung darat, salah satunya adalah pembangunan jembatan.

Jembatan adalah suatu konstruksi yang berguna untuk meneruskan jalan melalui suatu rintangan yang berada lebih rendah, misalnya sungai, rawa, jalan, dan lain-lain. Perencanaan pembangunan jembatan harus diperhatikan seefektif dan seefisien mungkin, sehingga pembangunan jembatan dapat memenuhi syarat keamanan dan kenyamanan bagi para pengguna jembatan.

Keberadaan jembatan saat ini terus mengalami perkembangan, dari bentuk sederhana sampai paling kompleks, demikian juga bahan-bahan yang digunakan mulai dari bambu, kayu, beton, dan baja. Penggunaan bahan baja untuk saat ini sampai dimasa mendatang, khususnya struktur jembatan akan memberikan keuntungan terhadap perkembangan serta kelancaran sarana transportasi di seluruh daerah yang ada di Indonesia. Kota Samarinda sudah banyak melakukan pembangunan proyek jembatan yang berguna untuk melancarkan transportasi yang ada, salah satunya adalah jembatan Gelatik. Wilayah ini di aliri oleh anak aliran sungai Mahakam, yang menyebabkan terganggunya transportasi darat pada khususnya. Berdasarkan hal tersebut pemerintah membangun jembatan untuk mengatasi masalah tersebut. Jembatan sebelumnya yang telah dibangun pada tahun 1998 adalah jembatan komposit. Penelitian ini bertujuan untuk merencanakan ulang jembatan Gelatik menggunakan struktur jembatan rangka baja dengan metode Load And Resistance Factor Design (LRFD) dengan pertimbangan bahwa metode ini memberikan kelebihan-kelebihan dibandingkan metode yang telah dikembangkan sebelumnya.

\section{METODE PENELITIAN}

Sebelum melakukan penelitian maka dibuat langkah-langkah pelaksanaan alur kegiatan penelitian agar dapat berjalan 
sistematis dan tepat sasaran tercapainya tujuan penelitian. Langkah awal yang perlu dilakukan adalah studi pendahuluan yang terdiri dari latar belakang, rumusan masalah, dan tujuan perencanaan. Selanjutnya dilakukan perhitungan perencanaan dari data awal yang diperoleh.

\section{Pengumpulan Data}

Jembatan Gelatik berlokasi di Jl. Gelatik, Temindung Permai Kecamatan Sungai Pinang Kota Samarinda. Teknik pengumpulan data dalam penelitian kuantitatif dengan teknik wawancara, dan melakukan observasi secara langsung dilokasi serta studi literatur.

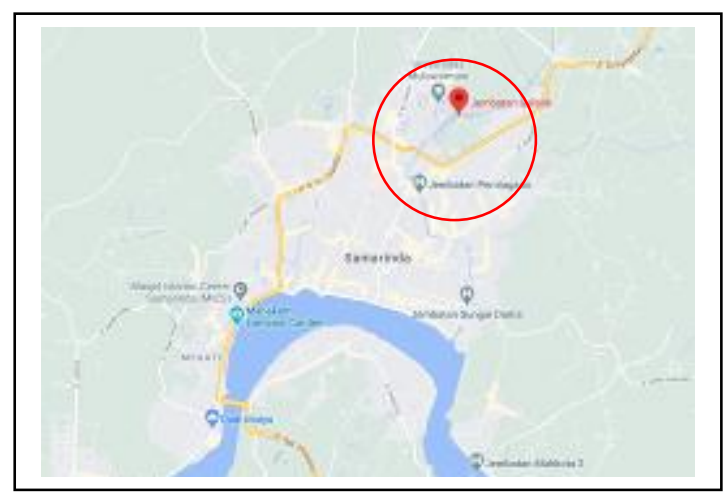

Gambar 1. Lokasi Jembatan Gelatik

Data awal yang diperoleh dari survey di jembatan Gelatik adalah sebagai berikut :

Panjang jembatan : : 39,00 meter

Lebar lantai kendaraan : 7,00 meter

Lebar trotoir $\quad: 2 \times 0,5$ meter

Tipe jembatan : Jembatan Komposit

Data perencanaan ulang

Panjang Jembatan : 39 jembatan

Gelatik adalah sebagai berikut :,00 meter

Lebar lantai kendaraan : 7,00 meter

Lebar trotoir $\quad: 2 \times 0,5$ meter

Lebar total jembatan $\quad: 8,00$ meter

Tinggi jembatan : 6,00 meter

Tipe jembatan : Trapesium rangka baja

Jarak antar gelagar memanjang: 1,40 meter

Jarak antar gelagar melintang : 3,25 meter

Mutu baja konstruksi : : St-37

Mutu beton karakteristik : K-225

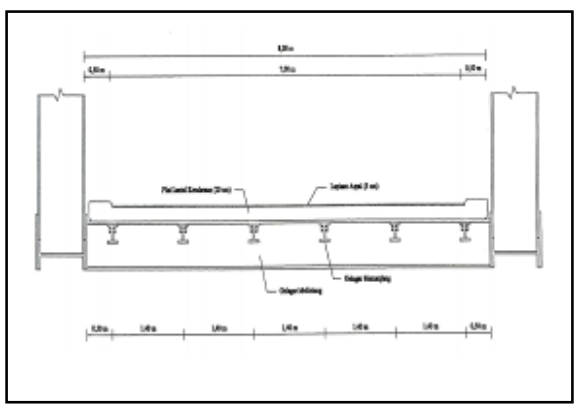

Gambar 2. Potongan Melintang Jembatan

Data pembebanan jembatan Gelatik adalah sebagai berikut :

Lapisan Aspal Lantai Kendaraan :

- Tebal lapisan aspal

: 0,05 meter

- Berat jenis aspal : $2200 \mathrm{Kg} / \mathrm{m}^{3}$ (SNI 1725-2016, hal 13)

Pelat Beton Lantai Kendaraan :

- Tebal plat beton : 0,2 meter

- Berat jenis beton bertulang :2400 Kg/m (SNI 1725-2016, hal 13)

Pelat beton trotoir :

- Tebal plat beton : : 0,4 meter

- Tebal tegel + spesi : 0,05 meter

- Berat jenis beton bertulang: $2200 \mathrm{Kg} / \mathrm{m}^{3}$ (SNI 1725-2016, hal 13)

Air hujan :

- Tinggi air hujan (asumsi): 0,05 meter

- Berat jenis air hujan :1000 $\mathrm{Kg} / \mathrm{m}^{3}$ 1725-2016, hal 11)

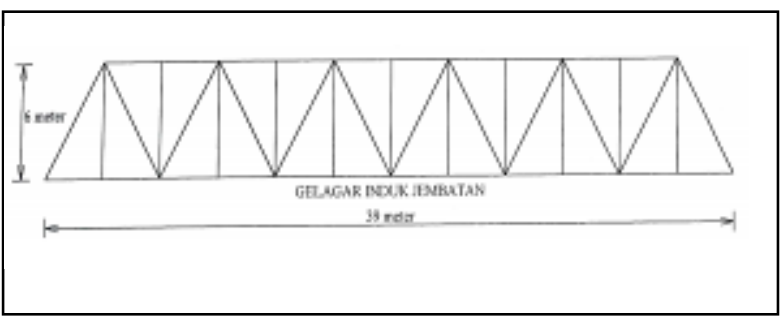

Gambar 3. Potongan Memanjang Jembatan

\section{Standar Perencanaan}

1. SNI 1725-2016, Pembebanan Untuk Jembatan.

2. SNI 3967-2008, Spesifikasi Bantalan Ealstomer Tipe Polos dan Tipe Berlapis Pada Jembatan.

3. SNI 1729-2015, Tentang Spesifikasi Untunk Bangunan Gedung Baja Struktural.

4. SNI 2833-2016, Tentang Standar Perencanaan Ketahanan Gempa Untuk Jembatan. 
5. Surat Edaran Menteri Pekerjaan Umum dan Perumahan Rakyat, No. 10/SE/M/2015; Tentang Pedoman Perancangan Bantalan Elastomer Untuk Perletakan Jembatan.

6. Analisa Struktur Jembatan rangka baja.

\section{Bagan Alir}

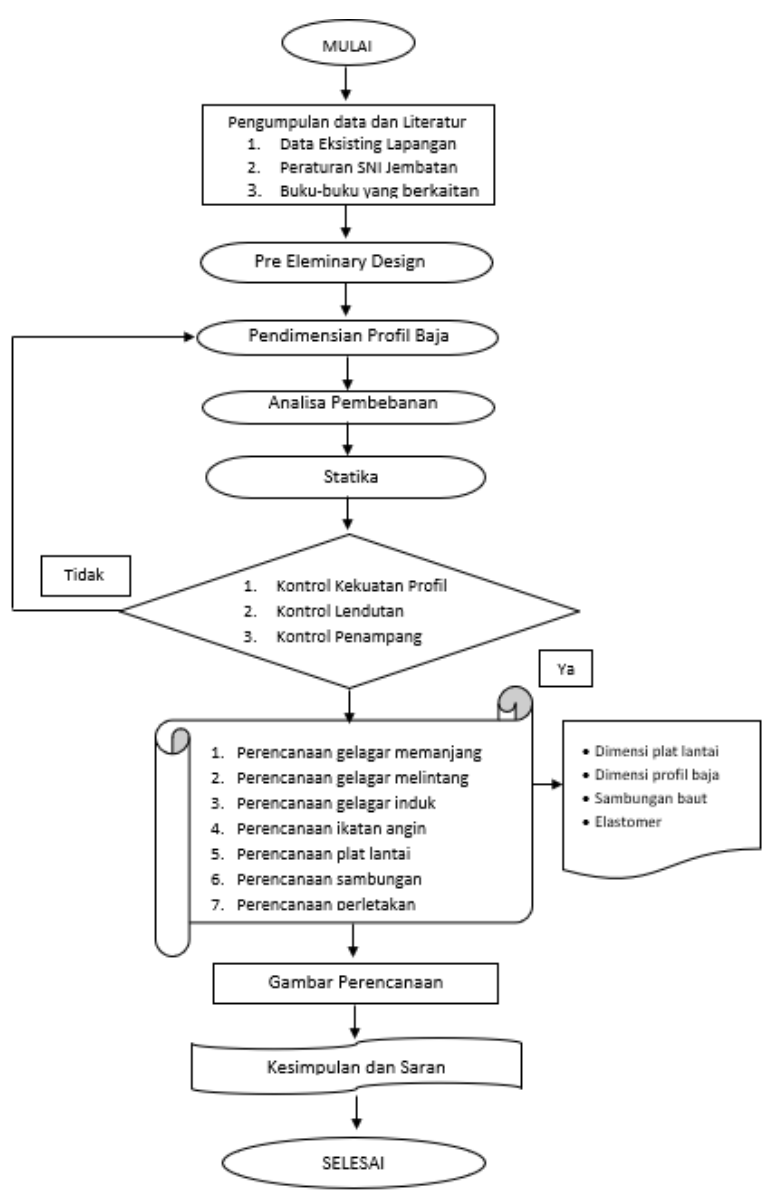

Gambar 4. Bagan Alir Perencanaan

\section{DASAR TEORI}

\section{Beban Tetap}

- Berat sendiri

Berat sendiri dari bangunan adalah aksi yang berasal dari berat sendiri jembatan serta elemen-elemen stuktural lain yang dipikulnya.

Tabel 1. Faktor beban untuk berat sendiri

\begin{tabular}{|c|c|c|}
\hline $\begin{array}{l}\text { Jangka } \\
\text { Waktu }\end{array}$ & Bahan & $\begin{array}{l}\text { Faktor } \\
\text { Beban }\end{array}$ \\
\hline \multirow{3}{*}{ Transien } & Baja, aluminium & 1,1 \\
\hline & Beton pracetak & 1,2 \\
\hline & Beton dicor di tempat & 1,3 \\
\hline
\end{tabular}

\section{\begin{tabular}{cc}
\hline Kayu & 1,4
\end{tabular} \\ Sumber : SNI 1725 : 2016 Pembebanan Untuk Jembatan}

- Beban Mati Tambahan

Beban mati tambahan adalah berat seluruh bahan yang membentuk suatu beban pada jembatan yang merupakan elemen non struktural dan mungkin besarnya berubah selama umur jembatan.

Tabel 2. Faktor beban untuk beban mati tambahan

\begin{tabular}{|c|c|c|}
\hline Jangka Waktu & Bahan & $\begin{array}{l}\text { Faktor } \\
\text { Beban }\end{array}$ \\
\hline \multirow{2}{*}{ Transien } & Keadaan umum & 2,0 \\
\hline & Keadaan khusus & 1,4 \\
\hline
\end{tabular}

\section{Beban Lalu Lintas}

Beban Lajur "D"

Beban "D" mempunyai intensitas q $\mathrm{kPa}$ dengan besaran $\mathrm{q}$ tergantung pada panjang total yang dibebani $\mathrm{L}$ yaitu :

Jika $\mathrm{L} \leq 30 \mathrm{~m} ; \mathrm{q}=9,0 \mathrm{kPa}$

Jika $\mathrm{L} \geq 30 \mathrm{~m} ; \mathrm{q}=9,0$. $(0,5+15 / \mathrm{L}) \mathrm{kPa}$

Keterangan :

Q adalah intensitas beban terbagi rata (UDL) yang digabung dengan beban garis (KEL)

$\mathrm{L}$ adalah panjang total jembatan yang dibebani (m).

Tabel 3. Faktor beban lajur "D"

\begin{tabular}{|c|c|c|c|}
\hline \multirow[b]{2}{*}{$\begin{array}{l}\text { Tipe } \\
\text { Beban }\end{array}$} & \multirow[b]{2}{*}{ Jembatan } & \multicolumn{2}{|c|}{ Faktor Beban } \\
\hline & & $\begin{array}{l}\text { Keadaan } \\
\text { Batas } \\
\text { Layan } \\
\left(\gamma_{T D}^{S}\right)\end{array}$ & $\begin{array}{l}\text { Keadaan } \\
\text { Batas } \\
\text { Ultimit } \\
\left(\gamma_{T D}^{U}\right)\end{array}$ \\
\hline & Beton & 1,00 & 1,80 \\
\hline Transien & $\begin{array}{l}\text { Boks } \\
\text { girder } \\
\text { baja }\end{array}$ & 1,00 & 2,00 \\
\hline \multicolumn{4}{|c|}{$\begin{array}{c}\text { Sumber : SNI } 1725: 2016 \text { Pembebanan Untuk } \\
\text { Jembatan }\end{array}$} \\
\hline \multicolumn{4}{|c|}{$\begin{array}{l}\text { Beban Truk "T" } \\
\text { Beban "T" adalah beban suatu kendaraan berat } \\
\text { dengan } 3 \text { gandar yang ditempatkan pada } \\
\text { beberapa posisi dalam lajur lalu-lintas rencana. }\end{array}$} \\
\hline
\end{tabular}


Tabel 4. Faktor beban lajur "T"

\begin{tabular}{clcc}
\hline \multirow{2}{*}{$\begin{array}{c}\text { Tipe } \\
\text { Beban }\end{array}$} & Jembatan & $\begin{array}{c}\text { Keadaan } \\
\text { Batas } \\
\text { Layan } \\
\left(\gamma_{T D}^{\mathrm{S}}\right)\end{array}$ & $\begin{array}{c}\text { Keadaan } \\
\text { Batas } \\
\text { Ultimit } \\
\left(\gamma_{T D}^{\mathrm{U}}\right)\end{array}$ \\
\hline \multirow{2}{*}{ Transien } & Beton & 1,00 & 1,80 \\
\cline { 2 - 4 } & $\begin{array}{l}\text { Boks } \\
\text { girder } \\
\text { baja }\end{array}$ & 1,00 & 2,00 \\
\hline
\end{tabular}

Sumber : SNI $1725: 2016$ Pembebanan Untuk Jembatan

Beban truk " $T$ " terdiri atas kendaraan truk semi-trailer yang mempunyai susunan dan berat gandar seperti terlihat dalam gambar 5 . Berat dari tiap-tiap gandar disebarkan menjadi 2 beban merata sama besar yang merupakan bidang kontak antara roda dengan permukaan lantai. Jarak antara 2 gandar tersebut bisa diubah-ubah dari 4,0 m sampai dengan 9,0 m untuk mendapatkan pengaruh terbesar pada arah memanjang jembatan.

Gambar 5. Pembeban Truk "T” (500 KN)

\section{Beban Dinamis}

Faktor beban dinamik (DLA) merupakan interaksi antara kendaraan yang bergerak dengan jembatan. Untuk truk "T" nilai DLA adalah 0,3. Untuk "KEL" nilai DLA diberikan dalam gambar berikut ini :

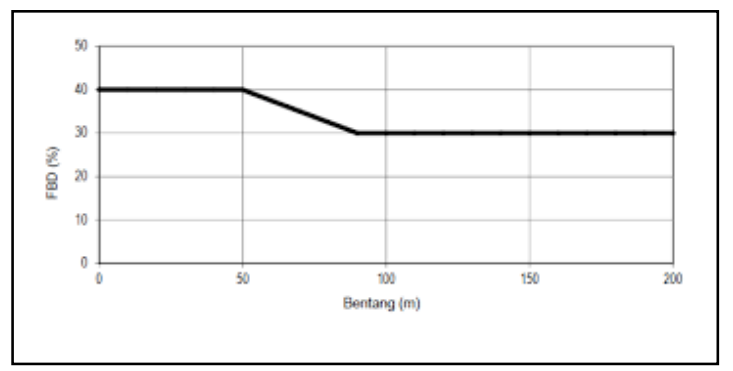

Gambar 6. Faktor beban dinamik untuk KEL untuk pembebanan lajur "D"

\section{Gaya Rem}

Gaya rem harus diambil yang terbesar :

- $25 \%$ dari berat gandar truk desain

- $5 \%$ dari berat truk rencana ditambah beban lajur terbagi rata BTR

Gaya rem tersebut harus ditempatkan di semua lajur rencana yang dimuati sesuai dengan Pasal 8.2 dan yang berisi lalu lintas dengan arah yang sama. Gaya ini harus diasumsikan untuk bekerja secara horizontal pada jarak $1800 \mathrm{~mm}$ diatas permukaan jalan pada masing-masing arah longitudinal dan dipilih yang paling menetukan. Untuk jembatan yang dimasa depan akan dirubah menjadi satu arah, maka semua lajur rencana harus dibebani secara simultan pada saat menghitung besarnya gaya rem. Faktor kepadatan lajur yang ditentukan pada Pasal 8.4.3 berlaku untuk menghitung gaya rem.

\section{Metode Load and Resistance Faktor Design (LRFD)}

LRFD (adalah spesifikasi yang dikeluarkan oleh AISC (America Instate Of Steel Construction) untuk desain konstruksi baja, berdasarkan ketahanan metode kekuatan ultimit (Metode Plastis). LRFD memberikan perbandingan yang lebih spesifik antara beban Q dan resistensi Rn, seperti persamaan untuk persyaratan mendapatkan keamanan sebagai berikut:

$$
\phi \mathrm{Rn} \geq \sum \gamma \mathrm{i} \mathrm{Qi}
$$

dimana ruas kiri mewakili resistensi (kekuatan) dari komponen atau sistem, sedangkan ruas kanan mewakili beban yang diharapkan akan ditanggung sehingga cenderung memberikan struktur yang lebih aman, Pada sisi kekuatan harga nominasi resistensi Rn dikalikan dengan faktor resistensi (reduksi kekuatan) $\phi$ untuk mendapatkan

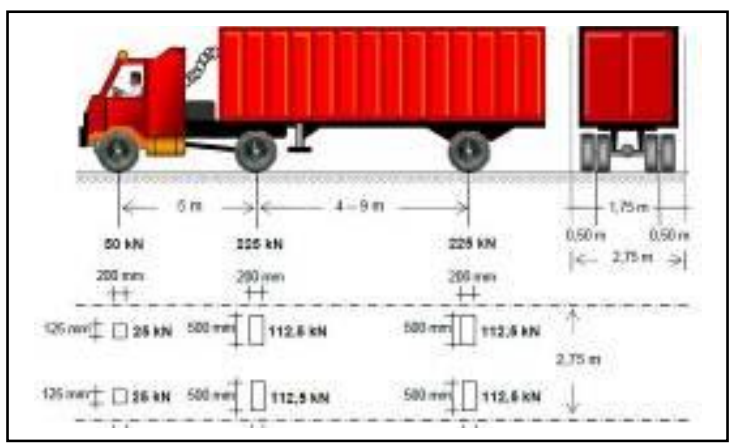

kekuatan desain. Pada sisi beban berbagai efek beban Qi (seperti beban mati, beban hidup, dan beban salju) dikalikan dengan faktorfaktor kelebihan beban $\gamma$ i untuk mendapatkan jumlah $\sum$ yi Qi dari beban-beban terfaktor. 
Vol. 4 No.2 Juni 2021

http://jurnal.umsb.ac.id/index.php/RANGTEKNIKJOURNAL

HASIL DAN PEMBAHASAN

Perhitungan Pembebanan Trotoir dan Lantai Kendaraan

Trotoir

Beban Mati Trotoir

Berat sendiri beton $\quad: 0,40 \times 1,00 \times 2400 \times$ $1,3=1248 \mathrm{Kg} / \mathrm{m}$

Berat tegel dan spesi $\quad 0,05 \times 1,00 \times 2200 \times$ $1,3=143 \mathrm{Kg} / \mathrm{m}$

Berat air hujan $\quad: 0,05 \times 1,00 \times 1000 \times$

$1,2=60 \mathrm{Kg} / \mathrm{m}$

$\mathbf{q}{ }^{\mathbf{u}}=1451 \mathrm{Kg} / \mathrm{m}$

\section{Beban Hidup Trotoir}

Konstruksi trotoir harus diperhitungkan terhadap beban hidup sebesar $\mathrm{q}=5 \mathrm{kPa}=500 \mathrm{Kg} / \mathrm{m}^{2} ;$ Faktor beban $=2,0$ (SNI 1725-2016, hal 46)

$\mathbf{q}_{2}{ }^{\mathbf{u}} \quad=500 \times 2=1000 \mathrm{Kg} / \mathrm{m}^{2}$

\section{Lantai Kendaraan}

Beban Mati Lantai Kendaraan

Berat sendiri beton $\quad: 0,20 \times 1,00 \times 2400 \times$ $1,3=624 \mathrm{Kg} / \mathrm{m}$

Berat lapisan aspal : 0,05 x 1,00 x $2200 \times 1,3=143 \mathrm{Kg} / \mathrm{m}$

Berat mati tambahan (aspal) : 0,05 x 1,00 x $2200 \times 2,0=220 \mathrm{Kg} / \mathrm{m}$

Berat air hujan $\quad: 0,05 \times 1,00 \times 1000 \mathrm{x}$ $1,2=60 \mathrm{Kg} / \mathrm{m}$

$\mathbf{q}{ }^{\mathbf{u}}=1047 \mathrm{Kg} / \mathrm{m}$

Beban Hidup "T"

Beban $\mathrm{T}$ adalah beban gandar truk maksimum sebesar

$500 \mathrm{KN}=50000 \mathrm{Kg}$; atau tekanan roda $=$ $112,5 \mathrm{KN}=11250 \mathrm{Kg}$; Faktor beban $=2,0$ (SNI 1725-2016, hal 41)

$\mathbf{P}^{\mathbf{u}} \quad=11250 \times 2=22500 \mathrm{Kg}$
Statika Pembebanan

Tabel 5. Statika Pembebanan

\begin{tabular}{|c|c|c|c|c|c|c|c|}
\hline \multirow{2}{*}{$\begin{array}{l}\mathrm{N} \\
\mathrm{o}\end{array}$} & \multirow{2}{*}{$\begin{array}{l}\mathrm{T} \\
\mathrm{u} \\
\mathrm{m} \\
\mathrm{p} \\
\mathrm{u} \\
\mathrm{a} \\
\mathrm{n}\end{array}$} & \multirow{2}{*}{$\begin{array}{l}\mathrm{L} \\
\text { ap } \\
\text { an } \\
\text { ga } \\
\mathrm{n}\end{array}$} & \multirow{2}{*}{$\begin{array}{c}\text { Mo } \\
\text { men } \\
\text { Akib } \\
\text { at } \\
\text { Beba } \\
\text { n } \\
\text { Mati } \\
\text { (Kg } \\
\text { m) }\end{array}$} & \multicolumn{2}{|c|}{$\begin{array}{c}\text { Momen } \\
\text { Akibat Beban } \\
\text { Hidup } \\
(\mathrm{Kgm})\end{array}$} & \multirow{2}{*}{$\begin{array}{c}\text { Kom } \\
\text { binas } \\
\text { i I } \\
(\mathrm{Kg} \\
\mathrm{m})\end{array}$} & \multirow{2}{*}{$\begin{array}{c}\text { Kom } \\
\text { binas } \\
\text { i II } \\
(\mathrm{Kg} \\
\mathrm{m})\end{array}$} \\
\hline & & & & $\begin{array}{l}\text { Kondi } \\
\text { si I }\end{array}$ & $\begin{array}{c}\text { Kond } \\
\text { isi II }\end{array}$ & & \\
\hline 1 & A & & $\begin{array}{r}1467 \\
, 752\end{array}$ & $\begin{array}{r}10822 \\
, 183\end{array}$ & $\begin{array}{r}2379 \\
493\end{array}$ & & \\
\hline 2 & B & & $\begin{array}{r}1454 \\
110\end{array}$ & $\begin{array}{r}17318 \\
, 903\end{array}$ & $\begin{array}{r}1765 \\
7,188\end{array}$ & & \\
\hline 3 & $\mathrm{C}$ & & $\begin{array}{r}1468 \\
138\end{array}$ & $\begin{array}{l}12349 \\
, 540\end{array}$ & $\begin{array}{r}2046 \\
3,323\end{array}$ & & \\
\hline 4 & $\mathrm{D}$ & & $\begin{array}{r}1468 \\
139\end{array}$ & $\begin{array}{l}13433 \\
, 119\end{array}$ & $\begin{array}{r}2046 \\
3,323\end{array}$ & & \\
\hline 5 & $\mathrm{E}$ & & $\begin{array}{r}1454 \\
108\end{array}$ & $\begin{array}{l}15178 \\
, 615\end{array}$ & $\begin{array}{r}1765 \\
7,184\end{array}$ & & \\
\hline 6 & $\mathrm{~F}$ & & $\begin{array}{r}1467 \\
, 753\end{array}$ & $\begin{array}{l}11887 \\
, 640\end{array}$ & $\begin{array}{r}2379 \\
494\end{array}$ & & \\
\hline 7 & & $\begin{array}{c}\mathrm{A} \\
-\mathrm{B}\end{array}$ & $\begin{array}{r}81,7 \\
28\end{array}$ & $\begin{array}{c}5294 \\
146\end{array}$ & $\begin{array}{r}2177, \\
379\end{array}$ & $\begin{array}{r}5375, \\
874\end{array}$ & $\begin{array}{r}2259 \\
107\end{array}$ \\
\hline 8 & & $\begin{array}{l}\text { B- } \\
\text { C }\end{array}$ & $\begin{array}{r}86,5 \\
98\end{array}$ & $\begin{array}{c}3512 \\
005\end{array}$ & $\begin{array}{r}1642 \\
361\end{array}$ & $\begin{array}{r}3598 \\
603\end{array}$ & $\begin{array}{r}1728 \\
959\end{array}$ \\
\hline 9 & & $\begin{array}{l}\text { C- } \\
\text { D }\end{array}$ & $\begin{array}{r}84,9 \\
59\end{array}$ & $\begin{array}{c}2989 \\
548\end{array}$ & $\begin{array}{r}1857 \\
639\end{array}$ & $\begin{array}{r}3074, \\
507\end{array}$ & $\begin{array}{r}1942, \\
598\end{array}$ \\
\hline $\begin{array}{l}1 \\
0\end{array}$ & & $\begin{array}{l}\mathrm{D} \\
-\mathrm{E}\end{array}$ & $\begin{array}{r}86,5 \\
99\end{array}$ & $\begin{array}{c}4063 \\
168\end{array}$ & $\begin{array}{r}1642 \\
361\end{array}$ & $\begin{array}{r}4149 \\
767\end{array}$ & $\begin{array}{r}1728, \\
96\end{array}$ \\
\hline $\begin{array}{l}1 \\
1\end{array}$ & & $\begin{array}{l}\text { E- } \\
F\end{array}$ & $\begin{array}{r}81,7 \\
28\end{array}$ & $\begin{array}{c}5853 \\
511\end{array}$ & $\begin{array}{r}2177, \\
379\end{array}$ & $\begin{array}{r}5935, \\
239\end{array}$ & $\begin{array}{r}2259 \\
107\end{array}$ \\
\hline
\end{tabular}

Setelah dihitung dengan Metode Cross, momen maksimum yang digunakan pada perhitungan plat lantai kendaraan didapat pada kombinasi I yaitu 5935,239 Kgm.

\section{Penulangan}

Penulangan Trotoir

Data perencanaan : Mutu beton K-225 ; f'c = 22,5 Mpa, Mutu Baja fy = $240 \mathrm{Mpa}$, Tebal Trotoir $\mathrm{hf}=0,4 \mathrm{~m}$, Diameter efektif direncanakan $\emptyset 18 \mathrm{~mm}$.

As pokok $\quad=\rho \times \mathrm{b} \times \mathrm{d}$

$$
=0,0058 \times 1000 \times 351
$$




$$
=2035,80 \mathrm{~mm}^{2}
$$

Digunakan tulangan pokok $\varnothing 18-100($ As $=$ $2544,7 \mathrm{~mm}^{2}$ )

$$
\begin{aligned}
\text { As bagi } & =20 \% \times \text { As pokok } \\
& =20 \% \times 2035,80 \\
& =407,160 \mathrm{~mm}^{2}
\end{aligned}
$$

Digunakan tulangan bagi $\varnothing 8-100($ As $=502,7$ $\mathrm{mm}^{2}$ )

\section{Penulangan Lantai Kendaraan}

Data perencanaan : Mutu beton K-225 ; f'c = 22,5 Mpa, Mutu Baja fy = $240 \mathrm{Mpa}$, Tebal plat lantai kendaraan $\mathrm{hf}=0,2 \mathrm{~m}$, Diameter efektif direncanakan $\varnothing 18 \mathrm{~mm}$.

As pokok

$$
\begin{aligned}
& =\rho \times \mathrm{b} \times \mathrm{d} \\
& =0,015 \times 1000 \times 151 \\
& =2265 \mathrm{~mm}^{2}
\end{aligned}
$$

Digunakan tulangan pokok $\varnothing 18-100($ As $=$ $2544,7 \mathrm{~mm}^{2}$ )

As bagi

$$
\begin{aligned}
& =20 \% \times \text { As pokok } \\
& =20 \% \times 2265 \\
& =453 \mathrm{~mm}^{2}
\end{aligned}
$$

Digunakan tulangan bagi $\varnothing 8-100($ As $=502,7$ $\mathrm{mm}^{2}$ )

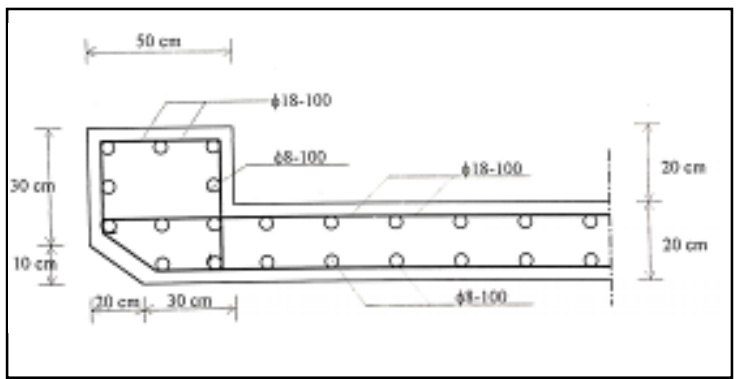

Gambar 7. Penulangan Trotoir dan Plat Lantai

\section{Perhitungan Gelagar Memanjang}

\section{Pembebanan}

Jarak gelagar memanjang $\quad=1,40$ meter

Jarak gelagar melintang $=3,25$ meter

\section{Beban Mati}

Beban terbesar dari gelagar tepi :

$\mathrm{q}_{\mathrm{u}}=1391,614 \mathrm{Kg} / \mathrm{m}^{\prime}$

\section{Beban Hidup}

Muatan terbagi rata : $\quad \mathrm{q}_{\mathrm{u}}=2240 \mathrm{Kg} / \mathrm{m}$

$$
\text { Beban garis : } \quad \mathrm{P}_{\mathrm{u}}=12320 \mathrm{Kg} / \mathrm{m}
$$

\section{Perhitungan Momen yang terjadi}

\section{Akibat Beban Mati}

$$
\begin{aligned}
\mathrm{M}_{\mathrm{BS}}{ }^{\mathrm{u}} & =\left(\frac{1}{8} \cdot q^{u} \cdot L^{2}\right) \\
& =\left(\frac{1}{8} \cdot 1391,614 \cdot 3,25^{2}\right) \\
& =1837,365 \mathrm{Kgm}
\end{aligned}
$$

Akibat Beban Hidup

$$
\begin{aligned}
& \operatorname{MD}^{\mathrm{u}}=\left(\frac{1}{8} \cdot q^{u} \cdot L^{2}\right)+\left(\frac{1}{4} \cdot P^{u} \cdot L\right) \\
& =\left(\frac{1}{8} \cdot 2240 \cdot 3,25^{2}\right)+\left(\frac{1}{4} \cdot 12320 \cdot 3,25\right) \\
& =12967,5 \mathrm{Kgm}
\end{aligned}
$$

\section{Akibat profil}

Direncanakan menggunakan WF 12 x 31

$\mathrm{G}=46,13 \mathrm{~kg} / \mathrm{m} \times 1,1=50,743 \mathrm{Kg} / \mathrm{m}$

$\mathrm{I}_{\mathrm{x}}=9924 \mathrm{~cm}^{4}$

$\mathrm{W}_{\mathrm{x}}=645,8 \mathrm{~cm}^{3}$

Momen akibat berat sendiri profil

$$
\begin{aligned}
& \mathrm{M}_{\mathrm{BS} \text { Profil }}=\left(\frac{1}{8} \cdot G \cdot L^{2}\right) \\
& =\left(\frac{1}{8} \cdot 50,743 \cdot 3,25^{2}\right)=66,997 \mathrm{Kgm} \\
& \mathrm{M}_{\text {tot }}=\mathrm{M}_{\mathrm{BS}}{ }^{\mathrm{u}}+\mathrm{MD}^{\mathrm{u}}+\mathrm{M}_{\mathrm{BS} \text { Profil }} \\
& =1837,365+12967,5+66,997 \\
& =14871,862 \mathrm{Kgm}=1487186,2 \mathrm{Kgcm}
\end{aligned}
$$

\section{Kontrol Konstruksi}

Kontrol Tegangan

$$
\begin{aligned}
\sigma & =\frac{M_{\text {tot }}}{W_{x}} \\
& =\frac{1487186,2}{645,8} \\
& =2320,859 \mathrm{~kg} / \mathrm{cm}^{2}<2400 \mathrm{~kg} / \mathrm{cm}^{2}
\end{aligned}
$$

\section{Kontrol Lendutan}

$$
\begin{aligned}
\bar{f} & =\frac{1}{250} . \mathrm{L} \\
& =\frac{1}{250} \cdot 325=1,30 \mathrm{~cm}
\end{aligned}
$$

$f=\frac{5}{384} \cdot \frac{q \cdot L^{4}}{E I}$

$\frac{5 \cdot(13,91614+22,40+0,50743) \cdot 325^{4}}{384 \cdot 2,1^{6} \cdot 9924}+$

$12320 \cdot 325^{3}$

$48.2,1.10^{6} .9924$

$$
=0,680 \mathrm{~cm}<1,30 \mathrm{~cm} \quad \text { (AMAN) }
$$

\section{Perhitungan Gelagar Melintang}

Pembebanan

Beban Mati

Akibat berat lantai kendaraan :

$\mathrm{q}_{\mathrm{u}}=973,710 \mathrm{Kg} / \mathrm{m}^{\prime}$

Akibat berat trotoar :

$\mathrm{q}_{\mathrm{u}}=975,072 \mathrm{Kg} / \mathrm{m}^{\prime}$

Akibat profil memanjang:

$\mathrm{q}_{\mathrm{u}}=164,915 \mathrm{Kg}$

\section{Beban Hidup}


Beban D :

$\mathrm{q}_{1}{ }^{\mathrm{u}}=16922 \mathrm{Kg} / \mathrm{m}^{\prime}$

$\mathrm{q}_{2}{ }^{\mathrm{u}}=8461 \mathrm{Kg} / \mathrm{m}^{\prime}$

Beban Truk "T" :

$\mathrm{T}=20000 \mathrm{Kg}$

Beban Trotoar :

$\mathrm{q}^{\mathrm{u}}=3250 \mathrm{Kg} / \mathrm{m}^{\prime}$

\section{Perhitungan Statika}

Akibat berat sendiri lantai kendaraan dan trotoar $\quad\left(\mathrm{M}_{1}\right)=7789,850 \mathrm{Kgm}$

Akibat berat sendiri $\left(\mathrm{M}_{2}\right)=940,016 \mathrm{Kgm}$

Akibat beban hidup " $\mathrm{D}$ "

$$
\left(\mathrm{M}_{3}\right)=127708,219 \mathrm{Kgm}
$$

Akibat muatan "T" $\left(\mathrm{M}_{4}\right)=243,750 \mathrm{Kgm}$

Akibat muatan hidup trotoar

$$
\left(\mathrm{M}_{5}\right)=406,250 \mathrm{Kgm}
$$

Momen maksimum yang terjadi pada gelagar melintang :

$\mathrm{M}_{\max }=\mathrm{M} 1+\mathrm{M} 2+\mathrm{M} 3+\mathrm{M} 4+\mathrm{M} 5$

$=7789,850+940,016+127708,219+$

$243,750+406,250$

$=136844,335 \mathrm{Kgm}=13684433,5 \mathrm{Kgcm}$

Direncanakan menggunakan WF 27 x 145

$\mathrm{G}=215,8 \mathrm{Kg} / \mathrm{m} \times 1,1=237,38 \mathrm{Kg} / \mathrm{m}$

$\mathrm{I}_{\mathrm{x}}=225400 \mathrm{~cm}^{4}$

$\mathrm{W}_{\mathrm{x}}=6603,5 \mathrm{~cm}^{3}$

Momen akibat berat sendiri profil

$$
\begin{aligned}
& \mathrm{M}_{\mathrm{BS} \text { Profil }} \quad=\left(\frac{1}{8} \cdot q \cdot L^{2}\right) \\
& =\left(\frac{1}{8} \cdot 237,38 \cdot 8^{2}\right)=1899,040 \mathrm{Kgm} \\
& \mathrm{M}_{\text {tot }}=\mathrm{M}_{\max }+\mathrm{M}_{\mathrm{BS} \text { Profil }} \\
& =13684433,5+1899,040 \\
& =138743,375 \mathrm{Kgm}=13874337,5 \mathrm{Kgcm}
\end{aligned}
$$

\section{Kontrol Konstruksi \\ Kontrol Tegangan}

$$
\begin{aligned}
\sigma & =\frac{M_{\text {tot }}}{W_{x}} \\
& =\frac{13874337,5}{6603,5} \\
& =2101,058 \mathrm{~kg} / \mathrm{cm}^{2}<2400 \mathrm{~kg} / \mathrm{cm}^{2}
\end{aligned}
$$

\section{Kontrol Lendutan}

$$
\begin{aligned}
\mathrm{M}_{\mathrm{BS} \text { Profil }} & =\left(\frac{1}{8} \cdot q \cdot L^{2}\right) \\
13874337,5 & =\left(\frac{1}{8} \cdot q \cdot 800^{2}\right) \\
\mathrm{q} & =173,429 \mathrm{Kg} / \mathrm{cm}
\end{aligned}
$$

$$
\begin{aligned}
\bar{f} & =\frac{1}{250} \cdot \mathrm{L} \\
& =\frac{1}{250} \cdot 800 \\
& =3,20 \mathrm{~cm} \\
f & =\frac{5}{384} \cdot \frac{q \cdot L^{4}}{E I} \\
& =\frac{5}{384} \cdot \frac{173,429 \cdot 800^{4}}{2,1 \cdot 10^{6} \cdot 225400} \\
& =1,954 \mathrm{~cm}<3,2 \mathrm{~cm}
\end{aligned}
$$

(AMAN)

\section{Perhitungan Gelagar Induk \\ Pembebanan \\ Beban Mati}

Berat sendiri gelagar induk : $\mathrm{G}_{1}{ }^{\mathrm{u}}=47018,400 \mathrm{Kg}$

Berat sendiri gelagar memanjang: $\mathrm{G}_{2}{ }^{\mathrm{u}}=$ $11873,862 \mathrm{Kg}$

Berat sendiri gelagar melintang :

$$
\mathrm{G}_{3}{ }^{\mathrm{u}}=120351,660 \mathrm{Kg}
$$

Berat lantai kendaraan :

$$
\mathrm{G}_{4}{ }^{\mathrm{u}}=170352 \quad \mathrm{Kg}
$$

Berat trotoir :

$$
\mathrm{G}_{5}{ }^{\mathrm{u}}=48672 \quad \mathrm{Kg}
$$

Berat sendiri sandaran :

$$
\mathrm{G}_{6}{ }^{\mathrm{u}}=871,728 \mathrm{Kg}
$$

Berat sendiri ikatan angin atas :

$$
\mathrm{G}_{7}{ }^{\mathrm{u}}=22880 \quad \mathrm{Kg}
$$

Berat sendiri ikatan angin bawah : $\mathrm{G}_{8}{ }^{\mathrm{u}}=$ $27456 \mathrm{Kg}$

$$
\mathrm{G}_{\text {total }}{ }^{\mathrm{u}}=449475,65 \mathrm{~kg}
$$

\section{Beban Hidup}

Muatan terbagi rata : $\quad \mathrm{q}_{1}=1777 \quad \mathrm{Kg} / \mathrm{m}$

Beban yang diterima gelagar induk

$$
\mathrm{q}_{2}=242,318 \mathrm{Kg} / \mathrm{m}
$$

$$
q^{u}=78753,402 \mathrm{Kg}
$$

Beban yang diterima tiap titik buhul

$$
\mathrm{P}_{1}{ }^{\mathrm{u}}=\frac{78753,402}{12}=6562,784 \mathrm{Kg}
$$

Beban yang diterima tiap titik buhul tepi

$$
\mathrm{P}_{1}{ }^{\mathrm{u}}=\frac{6562,784}{2}=3281,392 \mathrm{Kg}
$$

Muatan akibat beban garis :

$$
\mathrm{P}_{1-2}=19250 \mathrm{Kg} / \mathrm{m}
$$

Beban yang diterima gelagar induk

$\mathrm{P}_{1-2}{ }^{\mathrm{u}}=38500 \mathrm{Kg}$

Beban yang diterima tiap titik buhul

$\mathrm{P}_{1}{ }^{\mathrm{u}}=\frac{38500}{12}=3208,333 \mathrm{Kg}$ 
Beban yang diterima tiap titik buhul tepi

$\mathrm{P}_{1}{ }^{\mathrm{u}}=\frac{3208,333}{2}=1604,167 \mathrm{Kg}$

Beban terpusat total akibat beban hidup yang diterima tiap titik buhul

$=6565,784+3208,333$

$=9771,117 \mathrm{Kg}$

Beban yang diterima tiap titik buhul tepi $\mathrm{P}_{1}{ }^{\mathrm{u}}=\frac{9771,117}{2}=4885,559 \mathrm{Kg}$

\section{Gaya Rem}

Panjang jembatan $\quad=39$ meter

Faktor beban $\quad=2,0$

Gaya rem yang terjadi $=250 \mathrm{KN}=25000 \mathrm{Kg}$

Gaya rem yang dipikul tiap gelagar

$\mathrm{P}_{1}=\frac{25000}{2}=12500 \mathrm{Kg}$

Gaya rem yang diterima tiap titik buhul

$\mathrm{P}_{1}{ }^{\mathrm{u}}=2083,334 \mathrm{Kg}$

Gaya rem yang diterima tiap titik buhul tepi $\mathrm{P}_{1}{ }^{\mathrm{u}}=\frac{2083,334}{2}=1041,667 \mathrm{Kg}$

\section{Beban Angin}

$\begin{array}{llr}\mathrm{T}_{\mathrm{EW} 1} & = & 129,600 \mathrm{Kg} \\ \mathrm{T}_{\mathrm{EW} 2} & = & 6499,800 \mathrm{Kg} \\ \mathrm{V}_{\mathrm{A}} & = & 2468,740 \mathrm{Kg}\end{array}$

Gaya pada titik buhul tengah, faktor beban $=$ 1,2

$\mathrm{P}_{1}{ }^{\mathrm{u}}=\frac{2468,740}{12} \cdot 1,2=246,874 \mathrm{Kg}$

Gaya pada titik buhul tepi

$\mathrm{P}_{2}{ }^{\mathrm{u}}=\frac{246,874}{2}=123,437 \mathrm{Kg}$

\section{Perhitungan Ikatan Angin Atas}

$\sum \mathrm{M}_{\mathrm{B}}=0$

$$
\begin{aligned}
\mathrm{H}_{\mathrm{A}} \cdot 6 & =\left(\mathrm{T}_{\mathrm{EW1} 1}, 1,933\right)+\left(\mathrm{T}_{\mathrm{EW} 2}, 3\right) \\
\mathrm{H}_{\mathrm{A}} & =\frac{(129,6.1,933)+(6499,8 \cdot 3)}{6} \\
\mathrm{H}_{\mathrm{A}} & =329,653 \mathrm{Kg}
\end{aligned}
$$

Gaya pada titik buhul tengah

$\mathrm{P}_{1}{ }^{\mathrm{u}}=\frac{3291,653}{12} \cdot 1,2=329,165 \mathrm{Kg}$

Gaya pada titik buhul tepi
$\mathrm{P}_{2}{ }^{\mathrm{u}}=\frac{329,165}{2}=164,583 \mathrm{Kg}$

Perhitungan Ikatan Angin Bawah

$\sum \mathrm{H}=0$

$\mathrm{H}_{\mathrm{A}}+\mathrm{H}_{\mathrm{B}}-\mathrm{T}_{\mathrm{EW} 1}-\mathrm{T}_{\mathrm{EW} 2}=0$

$3291,653+\mathrm{H}_{\mathrm{B}}-129,6-6499,8=0$

$\mathrm{H}_{\mathrm{B}}=3337,747 \mathrm{Kg}$

Gaya pada titik buhul tengah

$\mathrm{P}_{1}{ }^{\mathrm{u}}=\frac{3337,747}{12} \cdot 1,2=333,775 \mathrm{Kg}$

Gaya pada titik buhul tepi

$\mathrm{P}_{2}{ }^{\mathrm{u}}=\frac{3337,747}{2}=168,888 \mathrm{Kg}$

\section{Perencanaan Dimensi Profil Baja}

Dalam perencanaan struktur atas jembatan, penulis menggunakan perhitungan melalui program bantu STAAD PRO, dihasilkan panjang masing-masing batang berikut gaya batang tersebut baik berupa gaya tarik maupun gaya tekan.

Tabel 6. Gaya aksial terbesar yang bekerja pada batang gelagar induk untuk setengah bentang

\begin{tabular}{|l|c|c|c|c|}
\hline $\begin{array}{l}\text { Kelomp } \\
\text { ok } \\
\text { Batang }\end{array}$ & $\begin{array}{c}\text { Nom } \\
\text { or } \\
\text { Bata } \\
\text { ng }\end{array}$ & $\begin{array}{c}\text { Panja } \\
\text { ng } \\
(\mathrm{m})\end{array}$ & $\begin{array}{c}\text { Gaya Aksial (Kg) } \\
(+)\end{array}$ & $\begin{array}{c}\text { Tekan } \\
(-)\end{array}$ \\
\hline 1 & 2 & 3 & 4 & 5 \\
\hline $\begin{array}{l}\text { Batang } \\
\text { Bawah }\end{array}$ & 5 & 3,25 & $\begin{array}{c}175712, \\
86\end{array}$ & \\
\hline $\begin{array}{l}\text { Batang } \\
\text { Atas }\end{array}$ & 17 & 3,25 & & $\begin{array}{c}181671, \\
27\end{array}$ \\
\hline $\begin{array}{l}\text { Batang } \\
\text { Vertikal }\end{array}$ & 24 & 6,00 & $\begin{array}{c}18728,1 \\
9\end{array}$ \\
\hline $\begin{array}{l}\text { Batang } \\
\text { Diagon } \\
\text { al }\end{array}$ & 23 & 6,824 & & 117145, \\
\hline $\begin{array}{l}\text { Ikatan } \\
\text { Angin } \\
\text { Atas } \\
\text { Diagon } \\
\text { al }\end{array}$ & 220 & 4,317 & & 2466,26 \\
\hline $\begin{array}{l}\text { Ikatan } \\
\text { Angin } \\
\text { Atas } \\
\text { Vertikal }\end{array}$ & 109 & 8,00 & 4569,81 & \\
\hline $\begin{array}{l}\text { Ikatan } \\
\text { Angin } \\
\text { Bawah }\end{array}$ & 171 & 4,317 & 4820,91 & \\
\hline
\end{tabular}


Untuk menghindar terjadinya slip antar dua batang atau lebih harus diusahakan untuk semua batang pada gelagar induk menggunakan profil dengan tinggi yang sama. Selain untuk menghindari slip, beberapa keuntungan yang dapat diperoleh dengan penggunaan tinggi yang sama pada profil adalah :

a. Lebih ekonomis karena tidak memerlukan plat pengisi.

b. Mempermudah proses pengerjaan terutama untuk penyambungan.

c. Nilai estetika yang didapat lebih tinggi.

Pada tabel 5 dapat dilihat bahwa gaya terbesar pada batang atas yaitu batang 17 dengan $\mathrm{P}=$ $181671,27 \mathrm{Kg}$. Untuk selanjutnya batang akan direncanakan terlebih dahulu dimensinya sebagai acuan untuk perhitungan dimensi batang yang lainnya.

\section{Batang Atas}

Diketahui P $=-181671,27 \mathrm{Kg}$ (tekan) $\mathrm{F}_{\mathrm{y}} \quad=2400 \mathrm{Kg} / \mathrm{cm}^{2}$

Direncanakan menggunakan profil WF $300 \mathrm{x}$ $300 \times 12 \times 12$

Data :

$$
\begin{aligned}
& \mathrm{h}=294 \mathrm{~mm} \quad \mathrm{~A}=107,7 \mathrm{~cm}^{2} \quad \mathrm{ix}=12,5 \mathrm{~cm} \\
& \mathrm{~B}=302 \mathrm{~mm} \quad \mathrm{Ix}=16900 \mathrm{~cm}^{4} \text { iy }=7,16 \mathrm{~cm} \\
& \mathrm{t}_{1}=12 \mathrm{~mm} \quad \mathrm{Iy}=5520 \mathrm{~cm}^{4} \\
& \mathrm{t}_{2}=12 \mathrm{~mm} \quad \mathrm{~W}=84,5 \mathrm{Kg} / \mathrm{m} \text {, } \\
& \mathrm{F}_{\mathrm{cr}} \quad=\mathrm{F}_{\mathrm{y}} \cdot\left(1-\left(0,25 \cdot \lambda c^{2}\right)\right) \\
& \left.=2400 \text {. (1- }\left(0,25 \cdot 0,489^{2}\right)\right) \\
& =2256,527 \mathrm{Kg} / \mathrm{cm}^{2}
\end{aligned}
$$

Maka kekuatan tekan nominalnya adalah :

$\emptyset \mathrm{Pn}=\varnothing . \mathrm{Ag} . \mathrm{F}_{\mathrm{cr}}$

$$
\begin{aligned}
& =0,85 .(107,7) .(2256,527) \\
& =206573,764 \mathrm{Kg}>\mathrm{Pn}=181671,27
\end{aligned}
$$

$\mathrm{Kg}(\mathrm{Oke})$

\section{Batang Bawah}

Diketahui $\mathrm{Tu}=175712,86 \mathrm{Kg}$ (tarik)

Direncanakan menggunakan profil WF $300 \mathrm{x}$ $300 \times 12 \times 12$

Pada perencanaan ini digunakan baut dengan diameter $\mathrm{D}=7 / 8$ inchi $=2,223 \mathrm{~cm}$

Lebar yang harus diambil untuk lubang $=$ $2,223+0,1=2,323 \mathrm{~cm}$

Luas bersih penampang (An)

$$
=104,912 \mathrm{~cm}^{2}
$$

Luas efektif penampang :

$$
\begin{aligned}
\mathrm{Ae} & =\mathrm{U} \cdot \mathrm{An} \\
& =0,85 .(104,912)
\end{aligned}
$$

$$
=89,175 \mathrm{~cm}^{2}
$$

\begin{tabular}{|c|c|c|c|c|c|c|}
\hline $\begin{array}{l}\text { Kelangol } \\
\text { Brimg }\end{array}$ & $\begin{array}{c}\mathrm{Pa}_{1} / \mathrm{I}_{1} \\
{[\mathrm{Bg}]}\end{array}$ & Exol & of & a. In & $\begin{array}{c}\text { Pasig } \\
\text { Kerangingm }\end{array}$ & Kstranzm \\
\hline $\begin{array}{l}\text { Betrie } \\
\text { Arse }\end{array}$ & 151671,27 & $\begin{array}{c}\text { WF } \\
3 \times 0 \times 3)(x \times 12 \times 12\end{array}$ & $2005 \% 5,704$ & $\cdot$ & - & Arax \\
\hline $\begin{array}{l}\text { EAste } \\
\text { Benth }\end{array}$ & 175712,35 & $\begin{array}{c}\mathrm{WF} \\
3,0 \times 3)(\times 12 \times 12\end{array}$ & . & 252632 & 45,391 & Ansin \\
\hline $\begin{array}{l}\text { Betrre } \\
\text { tertisal }\end{array}$ & 18728,19 & $\begin{array}{c}\text { WF } \\
300 \times 3) \times x \times 12 \times 12\end{array}$ & - & 232338 & 83,799 & Artax \\
\hline $\begin{array}{l}\text { Batrag } \\
\text { Diascrnal }\end{array}$ & 117145,33 & $\begin{array}{c}\text { WFF } \\
y \times x 3 \times x \mathrm{~L} 2 \times 12\end{array}$ & $161957,6 \mathrm{~S}$ & - & - & Anzes \\
\hline $\begin{array}{l}\text { Thutn } \\
\text { Argin } \\
\text { dias } \\
\text { Dingenal }\end{array}$ & 2466,26 & $\begin{array}{c}1 \\
75 \times 7 / x 10\end{array}$ & 20235 & 285,355 & 29,724 & Awas \\
\hline $\begin{array}{l}\text { Tlutrn } \\
\text { Aagin } \\
\text { Asas } \\
\text { Vertical }\end{array}$ & $4 \leqslant 681$ & $\begin{array}{l}\text { WF } \\
\text { Sxl6 }\end{array}$ & 8529.49 & 65448 & 250 & Amax \\
\hline $\begin{array}{l}\text { Dxtsin } \\
\text { Axgin } \\
\text { Bewih }\end{array}$ & 4809,91 & $\frac{1}{\sin 91 \times 11}$ & 5407.735 & 35919,375 & 240,005 & Atrax \\
\hline
\end{tabular}

Retakan pada penampang bersih :

$$
\begin{aligned}
\emptyset_{\mathrm{t}} . \mathrm{Tn} & =\emptyset_{\mathrm{t}} . \mathrm{Fu} \cdot \mathrm{Ae} \\
& =0,75 \cdot 3700.89,175 \\
& =247460,625 \mathrm{Kg}
\end{aligned}
$$

Pelelehan pada penampang bruto :

$$
\begin{aligned}
\emptyset_{\mathrm{t}} . \mathrm{Tn} & =\varnothing_{\mathrm{t}} . \mathrm{Fu} . \mathrm{Ae} \\
& =0,90.1400 .107,7 \\
& =232632 \mathrm{Kg}>\mathrm{Tu}=175712,86 \mathrm{Kg} \\
& \quad(\text { Oke })
\end{aligned}
$$

Batang tarik harus memenuhi persyaratan batang.

$$
\frac{L}{r}=\frac{325}{7,16}=45,391 \leq 300
$$

Berdasarkan rasio kerampingan tersebut maka batang aman terhadap bahaya tekuk.

Selanjutnya perhitungan ditabelkan.

Tabel 7. Perencanaan dimensi batang

\section{Perencanaan Sambungan}

Sambungan gelagar memanjang dan gelagar melintang

Direncanakan menggunakan baut A 325 dengan Diameter $\mathrm{D}=3 / 4$ inchi $=19 \mathrm{~mm}$, Jarak ujung minimum yang digunakan $32 \mathrm{~mm}, \mathrm{~A}_{\mathrm{b}}=$ $2,834 \mathrm{~cm}^{2}$.

Kekuatan tarik baut, $\mathrm{Fu}^{\mathrm{b}}=125 \mathrm{KN}=12500$ $\mathrm{Kg}$.

Kekuatan Tarik Desain :

$$
\begin{aligned}
\varnothing \mathrm{Rn} & =\varnothing \cdot\left(0,75 \cdot \mathrm{Fu}^{\mathrm{b}}\right) . \mathrm{A}_{\mathrm{b}} \\
& =0,75 \cdot(0,75 \cdot 12500) \cdot 2,834 \\
& =19926,563 \mathrm{Kg}
\end{aligned}
$$

Kekuatan Geser Desain :

$$
\begin{aligned}
\varnothing \mathrm{Rn} & =\varnothing \cdot\left(0,60 \cdot \mathrm{Fu}^{\mathrm{b}}\right) \cdot \mathrm{m} \cdot \mathrm{A}_{\mathrm{b}} \\
& =0,65 \cdot(0,60 \cdot 12500) \cdot 2 \cdot 2,834 \\
& =27631,5 \mathrm{Kg}
\end{aligned}
$$

Kekuatan Tumpu Desain :

$$
\varnothing \mathrm{Rn}=\varnothing .(2,4 . \text { d. t . Fu) }
$$




$$
\begin{aligned}
& =0,75 \cdot(2,4 \cdot 1,9 \cdot 0,673 \cdot 3700) \\
& =8516,142 \mathrm{Kg}
\end{aligned}
$$

Kekuatan Nominal :

$$
\begin{aligned}
\mathrm{Tn} & =0,6 \cdot \mathrm{Fy} . \text { Aug } \\
& =0,6 \cdot 2400 \cdot(0,673 \cdot 28,338) \\
& =27462,923 \mathrm{Kg}
\end{aligned}
$$

Jumlah baut (n) :

$$
\mathrm{n} \quad=\frac{27462,923}{8516,142}=3,225 \approx 4 \text { buah }
$$

Ketebalan plat (t) :

$$
\begin{aligned}
\mathrm{t} & \geq \frac{P}{\emptyset \cdot F u \cdot L} \\
& \geq \frac{27462,923 / 8}{0,75 \cdot 3700 \cdot 3,2} \\
& \geq 0,387 \mathrm{~cm}
\end{aligned}
$$

Maka digunakan plat penyambung siku L 75.75 .10 dengan ketebalan $1,00 \mathrm{~cm}$.

Gambar 8. Sambungan gelagar memanjang dan gelagar melintang

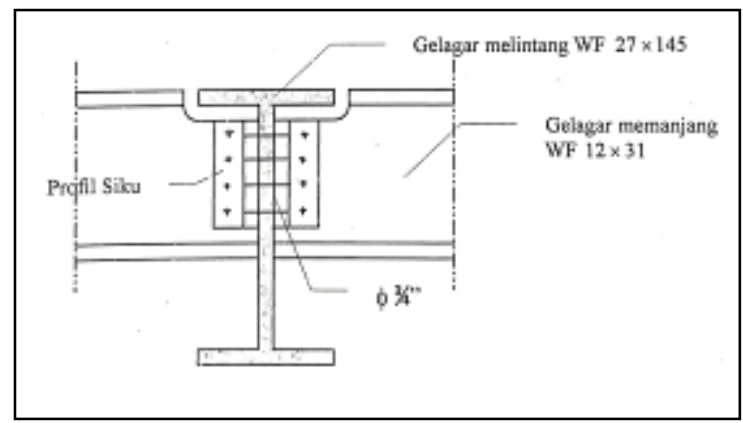

Sambungan gelagar melintang dan gelagar induk

Direncanakan menggunakan baut A 325 dengan Diameter $\mathrm{D}=3 / 4$ inchi $=19 \mathrm{~mm}$, Jarak ujung minimum yang digunakan $32 \mathrm{~mm}, \mathrm{~A}_{\mathrm{b}}=$ $2,834 \mathrm{~cm}^{2}$.

Kekuatan tarik baut, $\mathrm{Fu}^{\mathrm{b}}=125 \mathrm{KN}=12500$ $\mathrm{Kg}$.

Kekuatan Tarik Desain :

$$
\begin{aligned}
\varnothing \mathrm{Rn} & =\varnothing \cdot\left(0,75 \cdot \mathrm{Fu}^{\mathrm{b}}\right) \cdot \mathrm{A}_{\mathrm{b}} \\
& =0,65 \cdot(0,75 \cdot 12500) \cdot 2,834 \\
& =19926,563 \mathrm{Kg}
\end{aligned}
$$

Kekuatan Geser Desain :

$$
\begin{aligned}
\varnothing \mathrm{Rn} & =\varnothing \cdot\left(0,60 \cdot \mathrm{Fu}^{\mathrm{b}}\right) \cdot \mathrm{m} \cdot \mathrm{A}_{\mathrm{b}} \\
& =0,65 \cdot(0,60 \cdot 12500) \cdot 2 \cdot 2,834 \\
& =27631,5 \mathrm{Kg}
\end{aligned}
$$

Kekuatan Tumpu Desain :

Ketebelan plat yang diperhitungkan adalah ketebalan badan pada gelagar melintang yaitu $1,524 \mathrm{~cm}$.

$$
\begin{aligned}
\varnothing \mathrm{Rn} & =\varnothing \cdot(2,4 \cdot \mathrm{d} \cdot \mathrm{t} . \mathrm{Fu}) \\
& =0,75 \cdot(2,4 \cdot 1,9 \cdot 1,524 \cdot 3700) \\
& =19284,696 \mathrm{Kg}
\end{aligned}
$$

Kekuatan Nominal :

$$
\begin{aligned}
\text { Tn } & =0,6 . \text { Fy. Aug } \\
& =0,60 \cdot 2400 \cdot(1,524 \cdot 63,346) \\
& =139016,5968 \mathrm{Kg}
\end{aligned}
$$

Jumlah baut (n) :

$$
\mathrm{n} \quad=\frac{139016,598}{19284,696}=7,209 \approx 8 \text { buah }
$$

Ketebalan plat (t) :

$$
\begin{aligned}
\mathrm{t} & \geq \frac{P}{\emptyset \cdot F u \cdot L} \\
& \geq \frac{139016,598 / 16}{0,75 \cdot 3700 \cdot 3,2} \\
& \geq 0,978 \mathrm{~cm}
\end{aligned}
$$

Maka digunakan plat penyambung siku L 75.75.10 dengan ketebalan $1,00 \mathrm{~cm}$.

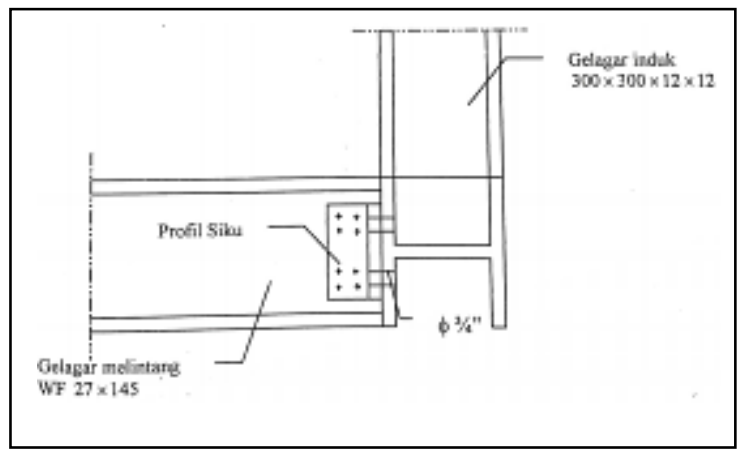

Gambar 9. Sambungan gelagar melintang dan gelagar induk

\section{Sambungan batang gelagar induk}

Direncanakan menggunakan baut A 326 dengan Diameter $\mathrm{D}=7 / 8$ inchi $=2,223 \mathrm{~cm}$, Jarak ujung minimum yang digunakan $32 \mathrm{~mm}$, $\mathrm{A}_{\mathrm{b}}=3,879 \mathrm{~cm}^{2}$.

Kekuatan tarik baut, $\mathrm{Fu}^{\mathrm{b}}=173 \mathrm{KN}=17300$ Kg.

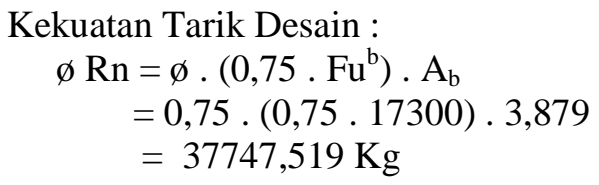

Kekuatan Geser Desain :

$$
\emptyset \mathrm{Rn}=\varnothing .\left(0,60 . \mathrm{Fu}^{\mathrm{b}}\right) . \mathrm{m} \cdot \mathrm{A}_{\mathrm{b}}
$$




$$
=26171,613 \mathrm{Kg}
$$

Kekuatan Tumpu Desain :

$$
\begin{aligned}
\varnothing \mathrm{Rn} & =\varnothing .(2,4 . \mathrm{d} . \mathrm{t} . \mathrm{Fu}) \\
& =0,75 \cdot(2,4 \cdot 2,223 \cdot 1,2 \cdot 3700) \\
& =17766,216 \mathrm{Kg}
\end{aligned}
$$

Jumlah baut (n) :

$$
\mathrm{n} \quad=\frac{117145,33}{17766,216}=6,59 \approx 8 \text { buah }
$$

Ketebalan plat (t) :

$$
\begin{aligned}
\mathrm{t} & \geq \frac{P}{\emptyset_{\cdot F u \cdot L}} \\
& \geq \frac{117145,33 / 8}{0,75 \cdot 3700 \cdot 6,0} \\
& \geq 0,879 \mathrm{~cm}
\end{aligned}
$$

Maka digunakan plat penyambung siku $\mathrm{L}$ 75.75.10 dengan ketebalan $1,00 \mathrm{~cm}$

Jarak antar baut $\geq \frac{R n}{F u, t}+\frac{d b}{2}$

$$
\begin{aligned}
& \geq \frac{F u_{P} t}{\emptyset \cdot P u \cdot t}+\frac{d b}{2} \\
& \geq \frac{117145,33 / 8}{0,75 \cdot 3700 \cdot 1,4}+\frac{2,223}{2} \\
& \geq 6,388 \mathrm{~cm}
\end{aligned}
$$

Syarat $: \geq 3 \cdot D=6,669 \mathrm{~cm}$

Untuk perencanaan ini digunakan jarak antar baut $14 \mathrm{~cm}$.

\section{Sambungan Ikatan Angin Atas dan Bawah}

Direncanakan menggunakan baut A 325 dengan Diameter $\mathrm{D}=3 / 4$ inchi $=1,9 \mathrm{~cm}, \mathrm{~A}_{\mathrm{b}}=$ $2,834 \mathrm{~cm}^{2}$.

Kekuatan tarik baut, $\mathrm{Fu}^{\mathrm{b}}=125 \mathrm{KN}=12500$

$\mathrm{Kg}$.

Kekuatan Tarik Desain :

$$
\begin{aligned}
\varnothing \mathrm{Rn} & =\varnothing \cdot\left(0,75 . \mathrm{Fu}^{\mathrm{b}}\right) . \mathrm{A}_{\mathrm{b}} \\
& =0,75 \cdot(0,75 \cdot 12500) \cdot 2,834 \\
& =19926,563 \mathrm{Kg}
\end{aligned}
$$

Kekuatan Geser Desain :

$$
\begin{aligned}
\varnothing \mathrm{Rn} & =\varnothing \cdot\left(0,60 \cdot \mathrm{Fu}^{\mathrm{b}}\right) \cdot \mathrm{m} \cdot \mathrm{A}_{\mathrm{b}} \\
& =0,65 \cdot(0,6 \cdot 12500) \cdot 1 \cdot 2,834 \\
& =13815,75 \mathrm{Kg}
\end{aligned}
$$

Kekuatan Tumpu Desain :

Direncanakan menggunakan profil $\mathrm{L}$

75.75.10 sehingga ketebalan plat siku yaitu $1,0 \mathrm{~cm}$.

$$
\begin{aligned}
\varnothing \mathrm{Rn} & =\varnothing \cdot(2,4 . \text { d. t } . \mathrm{Fu}) \\
& =0,75 \cdot(2,4 \cdot 1,9 \cdot 1,0.3700) \\
& =12654 \mathrm{Kg}
\end{aligned}
$$

Jumlah baut (n) :

$$
\mathrm{n} \quad=\frac{2466,26}{12654}=0,195 \approx 4 \text { buah }
$$

Ketebalan plat (t) :

$$
\begin{aligned}
\mathrm{t} & \geq \frac{P}{\emptyset \cdot F u \cdot L} \\
& \geq \frac{2466,260 / 4}{0,75 \cdot 3700 \cdot 4} \\
& \geq 0,056 \mathrm{~cm}
\end{aligned}
$$

Maka digunakan plat penyambung dengan ketebalan $0,5 \mathrm{~cm}$

$$
\begin{aligned}
\text { Jarak antar baut } & \geq \frac{R n}{F u_{.} t}+\frac{d b}{2} \\
& \geq \frac{P{ }^{\prime}}{\emptyset \cdot . t}+\frac{d b}{2} \\
& \geq \frac{2466,260 / 4}{0,75.3700 .1,0}+\frac{1,9}{2} \\
& \geq 1,172 \mathrm{~cm}
\end{aligned}
$$

Untuk perencanaan ini digunakan jarak antar baut $12 \mathrm{~cm}$.

\section{Perencanaan Perletakan}

Ukuran Landasan:

Digunakan beton K225 dengan tegangan ijin

$\overline{\sigma_{b k}}=75 \mathrm{Kg} / \mathrm{cm}^{2}$

$\mathrm{P}=112369,02 \mathrm{Kg}$

Luas blok beton

$$
\begin{aligned}
\mathrm{F} & =\frac{P}{\sigma_{b k}} \sigma_{b k} \\
& =\frac{112369,02}{75} \\
& =1498,254 \mathrm{~cm}^{2}
\end{aligned}
$$

\section{Perletakan Rol}

Panjang Perletakan

$$
\begin{aligned}
l & =\mathrm{L}+40 \\
& =39+40 \\
& =79 \mathrm{~cm}
\end{aligned}
$$

Tebal Bantalan

$$
\begin{aligned}
\mathrm{S}_{1} & =\frac{1}{2} x \sqrt{\frac{3 \cdot P \cdot l}{b \cdot \sigma_{b k}}} \\
& =\frac{1}{2} x \sqrt{\frac{3 \cdot 112369,02 \cdot 79}{20 \cdot 1600}} \\
& =11,777 \mathrm{~cm} \approx 15 \mathrm{~cm}
\end{aligned}
$$

Tebal Kursi

$$
\begin{aligned}
\mathrm{S}_{1} & =\frac{1}{2} \times \sqrt{\frac{3 \cdot P \cdot l}{b \cdot \sigma_{b k}}} \\
& =\frac{1}{2} \times \sqrt{\frac{3 \cdot 112369,02 \cdot 79}{20 \cdot 1600}} \\
& =11,777 \mathrm{~cm} \approx 15 \mathrm{~cm}
\end{aligned}
$$


Garis Tengah Rol

$$
\begin{aligned}
\mathrm{d}_{4} & =\frac{0,75 \cdot 10^{6} \cdot P}{l \cdot \sigma_{a}^{2}} \\
& =\frac{0,75 \cdot 10^{6} \cdot 112369,02}{79 \cdot 8500^{2}} \\
& =14,765 \mathrm{~cm} \approx 15 \mathrm{~cm}
\end{aligned}
$$

Garis Tengah Pergelangan Rol

Tebal pergelangan rol $\left(\mathrm{d}_{5}\right)$ diambil $2,50 \mathrm{~cm}$

$$
\begin{aligned}
\mathrm{d}_{3} & =\mathrm{d}_{4}+\left(2 \times \mathrm{d}_{5}\right) \\
& =15+(2 \times 2,5) \\
& =20 \mathrm{~cm}
\end{aligned}
$$

\section{Perletakan Sendi}

Tebal Bantalan $\left(\mathrm{S}_{1}\right)$

$$
\begin{aligned}
\mathrm{S}_{1} & =\frac{1}{2} x \sqrt{\frac{3 \cdot P \cdot l}{b \cdot \sigma_{b k}}} \\
& =\frac{1}{2} x \sqrt{\frac{3 \cdot 112369,02 \cdot 79}{20 \cdot 1600}} \\
& =11,777 \mathrm{~cm} \approx 15 \mathrm{~cm}
\end{aligned}
$$

Tebal Bantalan

$$
\begin{aligned}
\mathrm{S}_{1} & =\frac{1}{8} \cdot P \cdot l \\
& =\frac{1}{8} \cdot 112369,02 \cdot 79 \\
& =1109643,085 \mathrm{Kgcm}
\end{aligned}
$$

$\mathrm{W}=\frac{M}{\sigma_{d}}=\frac{1109643,085}{2400}=462,351 \mathrm{~cm}^{3}$

$\mathrm{S}_{3}=\frac{b}{4,2.3}=1,587 \mathrm{~cm} \approx 2 \mathrm{~cm}$

$\mathrm{S}_{2}=\frac{20}{4} \quad=5 \mathrm{~cm}$

$\mathrm{S}_{4}=\frac{20}{6} \quad=3,333 \mathrm{~cm} \approx 4 \mathrm{~cm}$

$\mathrm{S}_{5}=\frac{20}{9} \quad=2,222 \mathrm{~cm} \approx 3 \mathrm{~cm}$

Garis Tengah Sumbu Sendi $\left(\mathrm{d}_{1}\right)$

$$
\begin{aligned}
1 / 2 \mathrm{~d}_{1} & =\frac{0,8 P}{\sigma_{d} . l} \\
1 / 2 \mathrm{~d}_{1} & =\frac{0,8112369,02}{2700 \cdot 79} \\
1 / 2 \mathrm{~d}_{1} & =0,474 \\
\mathrm{~d}_{1} & =0,948 \mathrm{~cm}
\end{aligned}
$$

Untuk $\mathrm{d}_{1}$ diambil minimum $7 \mathrm{~cm}$

$\mathrm{d}_{4}=\frac{1}{4} \mathrm{~d}_{1}=\frac{1}{4} \cdot 7=1,75 \mathrm{~cm} \approx 2 \mathrm{~cm}$

$\mathrm{d}_{2}=\mathrm{d}_{1}+\left(2 \times \mathrm{d}_{3}\right)=7+(2 \times 2)=11 \mathrm{~cm}$

\section{PENUTUP \\ Simpulan}

Berdasarkan hasil analisa dari data dan perencanaan yang penulis lakukan, maka dapat disimpulkan bahwa dimensi plat dan tulangan yang dipakai pada lantai kendaraan dan trotoir pada perencanaan jembatan rangka baja adalah:

A. Plat Lantai Trotoir :

$\begin{array}{ll}\text { Panjang lantai kendaraan } & =39 \mathrm{~m} \\ \text { Lebar lantai kendaraan } & =0,5 \mathrm{~m} \\ \text { Jumlah trotoir rencana } & =2\end{array}$

Dipakai tulangan pokok $=\emptyset 18-100 \mathrm{~mm}$

Dipakai tulangan bagi $=\emptyset 8-100 \mathrm{~mm}$

B. Plat Lantai Kendaraan :

Panjang lantai kendaraan $\quad=39 \mathrm{~m}$

Lebar lantai kendaraan $\quad=7 \mathrm{~m}$

Dipakai plat beton $\quad=0,2 \mathrm{~m}$

Dipakai tulangan pokok $=\emptyset 18-100 \mathrm{~mm}$

Dipakai tulangan bagi $=\emptyset 8-100 \mathrm{~mm}$

C. Dimensi profil baja (WF) yang dipakai dalam perencanaan gelagar memanjang, gelagar melintang, dan gelagar induk :

a. Dimensi Gelagar Memanjang : WF 12 x 31

b. Dimensi Gelagar Melintang : WF $27 \mathrm{x}$ 145

c. Dimensi Gelagar Induk : WF 300 x 300 $\mathrm{x} 12 \times 12$

D. Dimensi perencanaan profil ikatan angin pada jembatang rangka :

a. Dimensi Ikatan Angin Atas Diagonal : L $75 \times 75 \times 10$

b. Dimensi Ikatan Angin Vertikal : WF $5 \mathrm{x}$ 16

c. Dimensi Ikatan Angin Bawah : L 90 x $90 \times 11$

E. Dimensi baut yang dipakai dalam perencanaan sambungan :

a. Sambungan Gelagar Memanjang dan Gelagar Melintang : Dipakai baut dengan dimensi $=\emptyset 19 \mathrm{~mm}$ Tebal Plat simpul $=10 \mathrm{~mm}$

b. Sambungan Gelagar Melintang dan Gelagar Induk : Dipakai baut dengan dimensi $=\emptyset 19 \mathrm{~mm}$

Tebal Plat simpul $=10 \mathrm{~mm}$

c. Sambungan Batang Gelagar Induk :

Dipakai baut dengan dimensi $=\emptyset 22,23$ $\mathrm{mm}$

Tebal Plat simpul $=10 \mathrm{~mm}$

d. Sambungan Ikatan Angin Atas dan Bawah : Dipakai baut dengan dimensi = $\emptyset 19 \mathrm{~mm}$ 
Tebal Plat simpul $=5 \mathrm{~mm}$

F. Dimensi perletakan :

a. Perletakan Rol :

Panjang perletakan $79 \mathrm{~cm}$, lebar 20 $\mathrm{cm}$, tinggi $20 \mathrm{~cm}$, dengan garis tengah rol $15 \mathrm{~cm}$.

b. Perletakan Sendi :

Panjang perletakan $79 \mathrm{~cm}$, lebar 20 $\mathrm{cm}$, tinggi $20 \mathrm{~cm}$, dengan susunan cover baja atas dan bawah setebal 5 $\mathrm{cm}$.

\section{Saran}

Perencanaan pembangunan jembatan selalu mengacu pada peraturan, standar ataupun landasan yang dikeluarkan oleh pihak yang berwenang, sehingga dalam pelaksanaannya hendaknya didasari oleh peraturan dan standar-standar yang berlaku dan standar yang terbaru.

\section{DAFTAR PUSTAKA}

Andi Sayamsudin, Eko Darma, Aminudin Azis. Perencanaan Struktur Bangunan Atas Jembatan Rangka Baja A-60 M di Kabupaten Supiori Provinsi Papua, Jurnal Bentang Vol.3 No.2, Juli 2015.

Anonim. 2016, Pembebanan Untuk Jembatan SNI T-1725-2016 Bandung : Badan Standarisasi Nasional.

Anonim. 2015, Tata Cara Perencanaan Baja Untuk Gedung SNI T-1729-2015 Bandung : Badan Standarisasi Nasional.

Anonim. 2008, Spesifikasi Bantalan Elastomer Tipe Polos dan Tipe Berlapis Untuk Perletakan Jembatan, SNI 3967-2008 Jakarta : Badan Standarisasi Nasional.

Anonim. 2000, Perencanaan Struktur Baja Untuk Bangunan Gedung Menggunakan Metode LRFD, Institut Teknologi Bandung, Pusat Penelitian Antar Universitas Bidang Ilmu Rekayasa.

Dewabroto, Wiryanto 2016. "Struktur Baja Perilaku, Analisis \& Desain AISC 2010 Edisi ke-2". Tangerang, Jurusan Teknik Sipil UPH.

Husnul Arif, Azizah Rachmawati, Studi Alternatif Perencanaan Bangunan Atas Jembatan Sriwedari Dengan Menggunakan Rangka Baja 3 Bentang Sungai Bengawan Solo Kabupaten Ngawi, Jurnal Rekayasa Sipil, Volume.5, Nomor.2, Tahun 2017.

Febry Suhendra, Faisal Ananda, Alamsyah, Perencanaan Jembatan Rangka
Pelengkung Sungai Liong, Jurnal Teknik Sipil, Volume.2, Nomor. 2, Tahun 2018.

Jimu Fernando Ghello, Sudirman Indra, Agus Santosa, Studi Alternatif Perencanaan Struktur Atas Jembatan Rangka Baja Tipe Pelengkung, Jurnal Gelagar, Volume.2, Nomor.1 Tahun 2020.

Rafika Sari Dewi, Rini Pratiwi Annur, Moga Narayudha, Siti Hardiyati. Perencanaan Alternatif Desain Jembatan Jurang Gempal Kabupaten Wonogiri, Jurnal Karya Teknik Sipil, Volume 5, Nomor 1, Hal 122-134, Tahun 2016.

Salmon, CG. Johnson, JE. 1992. Struktur Baja Desain dan Perilaku Jilid 1 : PT. Gramedia Pustaka Utama.

Setiawan, Agus. 2008. Perencanaan Struktur Baja Dengan Metode LRFD. (Berdasarkan SNI 03-1729-2002), Jakarta, Penerbit Erlangga.

Setiawan, Agus. 2013. Perencanaan Struktur Baja Dengan Metode LRFD Edisi ke-2. (Berdasarkan SNI 03-1729-2002), Jakarta, Penerbit Erlangga.

Struyk, H.j. Van Deer Veen, H.K.J.W, 1995. Jembatan Terjemahan Soemargono. Jakarta : PT. Pradya Paramita.

Sunggono kh, V, Ir, 1995. Buku Teknik Sipil, Bandung : Penerbit Nova. 